\title{
STUDENTS PERCEPTION ON CREATING VISUAL CULTURE ESSAY COLLABORATIVELY
}

\author{
Tamaela Ida Costansa \\ Germany Language Education Study Program, \\ Faculty of Teacher Training and Educational Sciences \\ Pattimura University, Ambon \\ email: idatamaela@yahoo.com
}

\begin{abstract}
The objective of this research is to find out students perceptions towards the implementation of creating visual culture essay collaboratively. It is a qualitative research in which the data were collected through questionnaire and interview. Ten students from the German education study program of Language and Art Department at Teachers Training and Educational Science faculty of Pattimura University, Ambon, took active participation in designing visual culture essay collaboratively.Based on the topic on culture provided by the lecturer, the group worked at the planning and designing stages of the visual culture essay. Each member of the group prepare his/her drawing accompanied by a short description to contribute to the group's visual essay. The research focuses on (1) students' perceptions on creating visual culture essay collaboratively, namely the facts and challenges, (2) the assessment result of students' design of visual culture essay. The research findings showstudents positive perceptions of the collaborative work. Moreover, the assessment result of their partly individual design ranges from 'acceptable' to 'exemplary', while the group's visual culture essay is categorized as 'acceptable'. Taking into consideration that this is the first time they designed a visual culture essay and designed it as a group, the result can be categorized as quite acceptable. When practiced on a regular basis undoubtedly the result will be quite an achievement.
\end{abstract}

Keywords: collaborative, perception; visual culture essay

\section{Introduction}

Writing is a subject which students find difficult and have problems with. Based on questionnaires distributed to ten students at the sixth semester of the German study program, it was revealed that the higher the level of writing the more difficult it is for them to produce a piece of writing. Therefore, in this research visual essay was applied to help students overcome their writing problem.

According to Slameto (2012:102) perception is a process concerning the message or information that goes into the human brain. Through perception people communicate with their environment through their senses, like seeing, listening, feeling, tasting, and smelling. Moreover, Walgito (2010:99) stated that perception is a process which starts with sensory, namely a sensory process where an individual receive a stimuli.

There are some relevant studies carried out in this field. One of them was the study carried out by Dom Cien (2017:902-918). He studied perceptions in respect to the teaching of English writing skill. A survey of 14 questions were applied to fifty-eight tenth graders of Jorge Icaza Education Unit in order to identify their perception regarding the writing 
skill and the methodology teachers use to teach it. It was identified that there was not an appropriate process of writing practice in the classroom.

A visual essay is a text that aims to communicate the ideas from another (source) text by using visual and verbal language. The visual language techniques in avisual essay are used to engage the audience and communicate the ideas from the source text as effectively as possible.

Dominique Macaire (2004:8) stated: "das BildergeltenalsleichtverständlicheMittel der Kommunikation, man meint dass sie einfacher als fremdsprachlicheTexte zuverstehen seien".

In other words, visuals are communication tools which are easy to understand rather than a text in a foreign language.Furthermore, she stated:

"auch landeskundlich schwierige und interessante Dinge, wie etwa Sprichwoerter, koennen veranschaulicht werden - zumindest wird das versucht". This means that aspects that are difficult and interesting in the field of history, such as utterances can be illustrated. The kind of visual in this research is drawing illustrations as explained by Macclaire (2004:71). That illustration is more or less closely related to references or objects which happens in reality. Additionally, she stated that (2004:60), working with visuals (drawings) can create a convenient and enjoyable atmosphere and students can express their emotions positively.

According to the institut für JPR FH Gelsenkirchen: "that visuals are signs or illustrations that can be seen with the eyes as sensory organ. Alltun (2015) did a study on how to help English language teachers to teach more effectively. She mentioned that drawing objects on the board is very exciting for learners in that it allows students to acquaint themselves with new vocabulary and quick memorization. It would be most appropriate if the words were to be nouns, as it would allow demonstration or drawings on the board. It is not required for a teacher to be knowledgeable in art, yet a simple drawing can have a strong effect in enabling students to store vocabulary in their minds upon sight of the picture visualization of the words.

Collaborationis working together as a team consisting of several participants (students) working on a project. In line with this, Dietmar Rösler (2014:177) stated that "Kooperatives Lernen nennt man eine Form der Zusammen arbeit im Unterricht, für die bestimmte Regeln verabredet werden. Ziel des kooperativen Lernens im Deutschunterricht ist, dass sie lernen, dies gemeinsam zu tun, dabei also von einander zu profitieren. In other words, cooperative learning is learning together in class under certain rules which were agreed upon and profitable to each member of the team. This statement is strengthened by Funk (2014:48-49) who stated that "Man erreicht am besten durch Sozial formen wie, Partner - oder Gruppenarbeit".... which means that students can succeed in class through working in pairs or in groups.He added that the aim of collaborative learning is for weak students to be motivated and supported by smart students in class.

He further stated that"Die LernendenkönnengemeinsamSchreibübungenmachen und gemeinsamTexteschreiben. Dabei können die Lernenden ihre Ideen austauschen und sich gegen seitig beim Schreiben unterstützen." (2014:122). In other words, students practice writing collaboratively where they can share ideas and support each other in producing a piece of writing.

Received September $18^{\text {th }} 2020$, Revision October $14^{\text {th }} 2020$, Accepted for publication October $19^{\text {th }} 2020$. Copyright (C) 2020 Published by FKIP - Unpatti, ISSN 2721-3110 
Chandra (2015) in another study on collaborative learning expressed that"collaboration is a way of interaction and personal attitude where individuals are responsible for their actions, their learning, and their abilities and contributions of their peers as well.

This paper clarifies the concept of collaborative learning by presenting and analyzing the educational benefits of collaborative learning techniques. Collaborative learning is more students centered.

It is expected that the teaching and learning of writing using visual essay method can help students to express ideas easily in written form and illustrate their imagination in visuals. According to Esser (2007:7) "moderner Literaturunterricht bearbeitet man wie Geschichten umgeschrieben und eigene Texte nach vorgegebenen Mustern verfasst werden. Daneben wird zuTexten gespielt und gemalt," .... which means thatmodern literature lessons can be rewritten like stories and own texts written according to predetermined patterns. In addition, free writing about the story which follows the existing literarytext pattern, becomes the result of the student's own writing in the form of Folk Story.

The aim of making drawings is for students to illustrate or describe an object or an incident which is experienced in order to tell it to the readers. Furthermore, through visuals, like drawings, the writings become more interesting. Students, in a sense, feel the problem that they put into their writings. This is a new experience for them.

In line with this,Funk (2014 : 146) stated, he was saying that he likes to work with his imagination and that it was not work, it was fun. It motivated his imagination and his thoughts. Then, visual essay was used.

Kearney (2016)stated that visual Essay uses images along with words in order to: (1) tell a personal story, (2) argue a claim, (3) explain a literary text, and (4) illustrate a social problem. He further stated that visual essays are more interesting and can have emotional impact and bigger audience since a picture paints a thousand words. Dominique (2004:23) stated thatpictures are suitable for presenting intercultural problems and misunderstandings. Ebert (2013:42) in his study mentioned that the functions of visual are thinking, comprehending, and improving what is written. Students did the activities in groups.

In relation to this, Lejeune (1999) mentioned that collaborative learning is an educational approach that involves groups of learners working together to solve a problem, complete a task, or create a product. It is based on the idea that learning is a naturally social act. Learning occurs though active engagement among peers, either face-to-face or online.

The main characteristics of collaborative learning are: a common task or activity; small group learning, co-operative behavior; interdependence; and individual responsibility and accountability. Therefore, through cooperative learning, students are expected to support and motivate each other and actively share ideas in order to write a folk story sequentially. In this way, students become interested and keen in writing stories and drawing pictures. Based on the discussion above, then this study is aimed at finding out students' perception of collaboratively writing a folk story through visual essay method. Thus, the research questions to be answered are:

a) What are students' perception of the implementation of visual essay method in improving their creative writing? 
b) What are students' perception on drawing pictures to accompany their visual culture essay?

\section{Research Method}

The population of this project were 10 sixth semester students at the German Study Program, Faculty of Teacher Training and Education, Pattimura University. Questionnaires were distributed to them. In the first part of the questionnaire students gave their opinion on the writing process prior to the study. In order to measure the quantitative results, a Likert Scale was used to structure a questionnaire regarding students' opinions. It consists of 13 items, and scores on a five point scale. (from 5=strongly agree; $4=$ agree; $3=$ neither agree/disagree; 2 =disagree; 1 =strongly disagree).

Table 1. Students' opinion on the writing process prior to the study

\begin{tabular}{|l|l|l|l|l|l|l|}
\hline No & \multicolumn{1}{|c|}{ Statements } & SA & A & N & D & SD \\
\hline 1 & I have heard about writing visual essays & & & & & \\
\hline 2 & The writing process improve my creativity & & & & & \\
\hline 3 & $\begin{array}{l}\text { Writing is only concerned with language knowledge and } \\
\text { not with the social world }\end{array}$ & & & & \\
\hline 4 & $\begin{array}{l}\text { I am able to choose and decide on a topic for my writing } \\
5\end{array}$ & & & & & \\
\hline 6 & $\begin{array}{l}\text { I am able to put my ideas sequentially in writing } \\
\text { because it is an advantage. }\end{array}$ & & & & \\
\hline 7 & I am doubtful whether I could draw good pictures & & & & & \\
\hline 8 & I can explain or describe abstract ideas & & & & & \\
\hline 9 & In writing, imagination is not necessary & & & & & \\
\hline 10 & I am able to make readers believe my writings. & & & & & \\
\hline 11 & I am able to write an essay on my own & & & & & \\
\hline 12 & $\begin{array}{l}\text { learning collaboratively is needed to produce a good piece } \\
\text { of writing }\end{array}$ & & & & \\
\hline 13 & I can write a concluding sentence & & & & & \\
\hline
\end{tabular}

The second part of the questionnaire which consists of 8 items asked for students' perception on working collaboratively using visual essay method.

Table 2. Students' perception on working collaboratively using visual essay method

\begin{tabular}{|l|l|l|l|l|l|l|}
\hline No & Statements & SA & A & N & D & SD \\
\hline
\end{tabular}

Received September $18^{\text {th }} 2020$, Revision October $14^{\text {th }} 2020$, Accepted for publication October $19^{\text {th }} 2020$. 


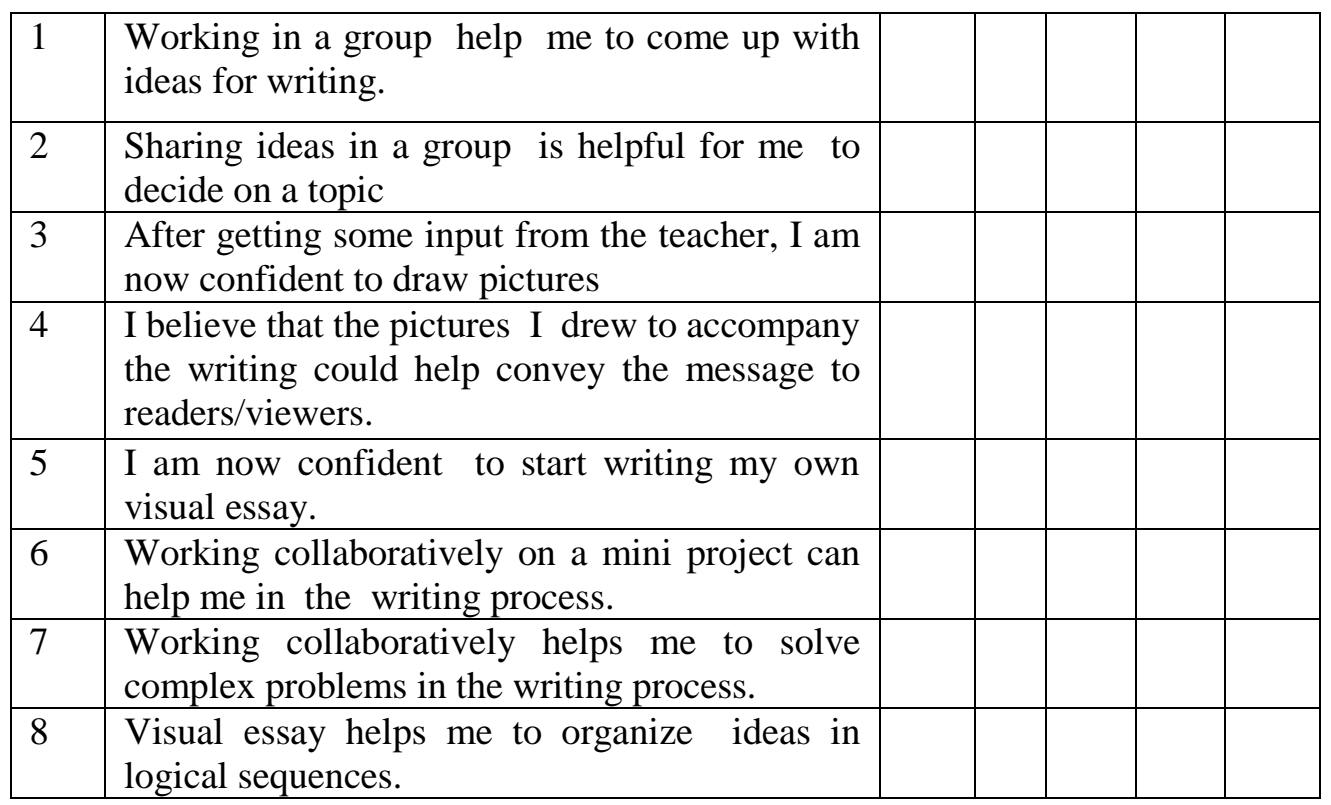

\section{Results and Discussion}

\section{a. Result}

\section{Result of Preliminary Study}

Prior to participating in the study on producing students' visual essay, a preliminary study was carried out to find out students' opinion and problems on the writing process. Table 1 shows the data which was obtained from students' questionnaires before they participated in the study on producing visual essay method.

Table 3. Students' opinion on the writing process prior to the study

\begin{tabular}{|l|c|c|c|c|c|c|c|c|c|c|c|c|c|}
\hline Ss & $\begin{array}{c}\text { Item } \\
\text { No.1 }\end{array}$ & $\begin{array}{c}\text { Item } \\
\text { no2 }\end{array}$ & $\begin{array}{c}\text { Item } \\
\text { no.3 }\end{array}$ & $\begin{array}{c}\text { Item } \\
\text { no.4 }\end{array}$ & $\begin{array}{c}\text { item } \\
\text { no.5 }\end{array}$ & $\begin{array}{c}\text { item } \\
\text { no.6 }\end{array}$ & $\begin{array}{c}\text { Item } \\
\text { no.7 }\end{array}$ & $\begin{array}{c}\text { Item } \\
\text { no.8 }\end{array}$ & $\begin{array}{c}\text { Item } \\
\text { no.9 }\end{array}$ & $\begin{array}{l}\text { Item } \\
\text { No.10 }\end{array}$ & $\begin{array}{l}\text { Item } \\
\text { no.11 }\end{array}$ & $\begin{array}{l}\text { Item } \\
\text { No.12 }\end{array}$ & $\begin{array}{l}\text { Item } \\
\text { No13 }\end{array}$ \\
\hline 1 & 5 & 2 & 4 & 2 & 4 & 1 & 5 & 1 & 4 & 2 & 1 & 5 & 1 \\
\hline 2 & 5 & 2 & 5 & 2 & 5 & 1 & 5 & 1 & 4 & 2 & 1 & 5 & 1 \\
\hline 3 & 5 & 1 & 5 & 2 & 5 & 2 & 5 & 1 & 4 & 2 & 1 & 5 & 1 \\
\hline 4 & 5 & 1 & 5 & 2 & 5 & 2 & 5 & 1 & 4 & 2 & 1 & 5 & 1 \\
\hline 5 & 5 & 1 & 5 & 2 & 4 & 1 & 5 & 1 & 4 & 2 & 1 & 3 & 1 \\
\hline 6 & 5 & 1 & 5 & 2 & 5 & 1 & 5 & 1 & 4 & 2 & 1 & 5 & 1 \\
\hline 7 & 5 & 2 & 4 & 2 & 4 & 2 & 5 & 1 & 3 & 2 & 2 & 4 & 1 \\
\hline 8 & 5 & 2 & 4 & 2 & 5 & 2 & 5 & 1 & 3 & 2 & 1 & 5 & 1 \\
\hline 9 & 5 & 1 & 5 & 2 & 5 & 5 & 5 & 1 & 4 & 2 & 2 & 2 & 1 \\
\hline 10 & 5 & 2 & 3 & 2 & 5 & 3 & 5 & 1 & 3 & 2 & 1 & 4 & 1 \\
\hline
\end{tabular}

For question number 1, all ten students (100\%) participating in the study strongly agreed that they have never heard about writing visual essay prior to this study. For question number 2, five students (50\%) strongly disagreed and five other students $(50 \%)$ disagreed 
that writing process improved their creativity. For question number 3, six students $(60 \%$ strongly agreed and three others (30\%) agreed that writing is only concerned with language knowledge and not with the social world, except for one student (10\%) who preferred to stay neutral. Furthermore, for question number 4,all participating students (100\%) disagreed that they were able to choose and decide on a topic for their writing. From the result of question number 5 , it can be seen that seven students (70\%) strongly agreed, and three students (30\%) agreed that they were not able to put their ideas sequentially in writing. Additionally, question number 6 shows that one student (10\%) was neutral, while 5 students (50\%) strongly disagreed and four students (40\%) disagreed that it was essential to have pictures to accompany their writing because it has no advantages. Students responses on question number 7 shows that ten students (100\%) strongly agreed that they were doubtful of whether they could draw good pictures, while for questions number 8 the same percentage responded that they strongly disagreed with the statement that they could explain or describe abstract ideas. For question number 9 , seven students $(70 \%)$ agreed that in writing, imagination is not necessary, while three students (30\%) preferred to choose the option'neutral'. Next, for question number 10, all ten students (100\%) disagreed with the statement that they were able to make readers believe their writings. For question number 11 , eight students $(80 \%)$ strongly disagreed and two students $(20 \%)$ disagreed with the statement that they wereable to write their own essay. For question number 12,six students $(60 \%)$ strongly agreed, two students (20\%) agreed, one student (10\%) neutral, one student $(10 \%)$ disagreed on the question 'learning cooperatively is needed to produce a good piece of writing'. Last, for question number 13, ten students (100\%) strongly disagreed that they could write a concluding sentence.

\section{Result of students' visual essay}

After brainstorming on the themes provided by the teacher, the group decided to explore the theme "culture". They then came to a group consensus of writing a folklore with the topic 'Brotherhood between BatuMerah and Passo'. BatuMerah and Passo are names of two villages inhabited by Moslems and Christians respectively. After each member of the group presented an idea, he/she wrote several sentences to support the idea in one paragraph. The next step was drawing a picture to accompany the paragraph. The writing process was carried out in German language.

Student 1. Before the Portuguese came to Ambon, the sultanate of Ternate had control over Maluku. The Sultan of Ternate issued an instruction or or a warrant to all states which were under his control to bring tribute (revenues/contributions) to Ternate every year.

Student 2. In 1506, two kora-kora (kind of boat) sailed to Ternate, namely kora-kora of Passso village which was a representative of Patalima and kora-kora from BatuMerah village which was a representative of Patasiwa.

Student 3. On the way back to Ambon island, exactly near the sea of Buru island, strong wind and high waves struck the kora-koraof Passo. As a result, the boat started to sink.

Student 4. Men were shouting for help. Luckily, the men on board the kora-kora of Batu Merah village was behind them. They saw the incident and helped the passengers who were at the kora-kora which was sinking. 
Student 5. Next, they all approached the shore of Buru island, near a cape. Having arrived, they all sat down near the shore. Since the men of Passo lost their tagalaya (kind of tray made of bamboo) in the sea accident, the men of BatuMerah village shared their food with them. Since there was not enough food left they then divided the food in equal share, such as sago, fish and coconut.

Student 6. After eating, the men of Passo village who were in tears and very thankful to the men of Batu Merah village, asked them to be their brothers, since they (the men of Batu Merah village) had saved their lives.

Student 7. The men of Batu Merah immediately responded sincerely saying that they are willing to accept them as their younger brother. They then agreed to make an oath to be together forever as brothers.

Student 8 . They flipped a coral reef at the cape and named it Pela Cape. When flipping the coral reef, blood came out of their fingers and while holding each other's hand they said their sacred oath which bond them.

Student 9. As a consequence of the oath natives of Passo were not allowed to marry natives of Batu Merah. They should not fight between them, they should help each other, such as preparing some materials for building a mosque and or a church.

Student 10. This sacred oath was practiced and maintained by ancestors of the two villages, and should be preserved from generation to generation.

\section{Results of Students' Perception on Producing Visual Essay}

Questionnaires were distributed to find out students' perception on the following matters: (1) writing creative essay using visual method (2) drawing pictures to accompany their creative essay (folklore) and (3) working cooperatively on the mini project to produce a creative essay (folklore) using visual essay method. The results of the questionnaires are shown in the following tables. After working collaboratively on the mini project in producing a creative writing, namely a folklore, using visual method essay, a questionnaire was distributed to find out students' perception on the study. Table 2 show the result. 
Table 4. Result of students' perception on working collaboratively using visual essay method

\begin{tabular}{|c|c|c|c|c|c|c|c|c|}
\hline Students & $\begin{array}{c}\text { Item } \\
\text { No.1 }\end{array}$ & $\begin{array}{c}\text { Item } \\
\text { No. 2 }\end{array}$ & $\begin{array}{c}\text { Item } \\
\text { No. 3 }\end{array}$ & $\begin{array}{c}\text { Item } \\
\text { No. 4 }\end{array}$ & $\begin{array}{c}\text { Item } \\
\text { No. 5 }\end{array}$ & $\begin{array}{c}\text { Item } \\
\text { No. 6 }\end{array}$ & $\begin{array}{c}\text { Item } \\
\text { No. 7 }\end{array}$ & $\begin{array}{c}\text { Item } \\
\text { No. } 8\end{array}$ \\
\hline 1 & 5 & 5 & 5 & 4 & 5 & 5 & 5 & 4 \\
\hline 2 & 5 & 5 & 5 & 4 & 4 & 4 & 5 & 5 \\
\hline 3 & 5 & 5 & 4 & 4 & 4 & 4 & 5 & 5 \\
\hline 4 & 5 & 5 & 4 & 4 & 5 & 5 & 5 & 4 \\
\hline 5 & 5 & 5 & 5 & 4 & 5 & 4 & 5 & 5 \\
\hline 6 & 5 & 5 & 4 & 4 & 4 & 4 & 5 & 5 \\
\hline 7 & 5 & 5 & 4 & 4 & 4 & 4 & 5 & 4 \\
\hline 8 & 5 & 5 & 5 & 4 & 5 & 4 & 5 & 4 \\
\hline 9 & 5 & 5 & 4 & 4 & 4 & 4 & 5 & 5 \\
\hline 10 & 5 & 5 & 4 & 4 & 4 & 4 & 5 & 4 \\
\hline
\end{tabular}

\section{b. Discussion}

From question number 1 and number 2 it is clear that all ten students (100\%) strongly agree that working in a group help them to come up with ideas for writing and that sharing ideas in a group help them to decide on a topic. For question number 3, four students (40\%) strongly agree and six students (60\%) agree that after participating in the study they now are confident to draw pictures. For question number 4 , all students $(100 \%)$ believe that the pictures they drew could help convey message to readers and viewers. For question number 5 , four students (40\%) strongly agreed and six students $(60 \%)$ agreed that they are now confident to start writing their own visual essay. Next, for question number 6,two students (20\%) strongly agree and eight students (80\%) agree that working cooperatively on a mini project can help them in the writing process.

Furthermore, for questionnumber 7, they all strongly agree that working collaboratively helps them solve complex problems in the writing process. Last, for question number 8, seven students (70\%) strongly agree and three students (30\%) agree that visual essay helped them organize ideas in logical sequences.

\section{Conclusion}

The results of the questionnaires show that students gain knowledge in writing folk stories through visual essay and their drawing skills were also put into practice. Moreover, their attitude towards writing also changed positively through working and learning collaboratively. It is also clear that their visual essays show their high critical thinking level andcreativity. It is hoped that this study will be a stepping stone for students to be successful in writing their visual essay individually.

\section{References}

Chandra,Rituin IOSR Journal of Resaerch and Method in Education. (IOSR-JRME) eISSN:2320 -7388,p.ISSN : 2320-737 X volume 5, Issue 3.Ver.I (Mai-June 2015), PP 04-07 http://www.iosrjournals.org/iosr-jrme/papers/Vol-5\%20Issue-3/Version1/B05310407.pdf 
Dietmar Rösler, Nicola Würffel, 2014, Lernmaterialien und Medien 5, Deutsch Lehren Lernen, München: Klett Langenscheidt

Dom Cien, ISSN:2477-8818 Vol.3, num 4 julio 2017 pp. 902-918. https://www.google.com/search?safe=strict\&ei=SB2kXMaXO9H-9QOH-

5ywDA\&q=Dom+Cien\%2C+ISSN\%3A2477-

Ebert Thomas 2013, Die Systematisierung visueller Darstellungsformen in der Sozialwissenschaftlichen Forschung, Inaugural-Dissertation zur Erlangung der Doktorwuerde des Fachsbereich Erziehungs wissenschaftlich der Philips Magburg, Universität Magburg

Esser Rolf 2007, Das grosse Arbeitsbuch Literaturunterricht, Lyrik Epik Dramatik, ISBN 978-3-8346-0234-3 Iserlohn:: Verlag an der Ruhr,

Funk Herman, Kuhn Christina, dkk, 2014, Deutsch Lehren Lernen, Aufgaben, Übungen, Interaktion 4, München: Klett-Langenscheidt p.48-49

Funk Herman, Kuhn Christina, dkk, 2014, Deutsch Lehren Lernen, Aufgaben, Übungen, Interaktion 4, München: Klett-Langenscheidt, p.146

Lejeune Colaborative Learning. http://clt.curtin.edu.au/teaching_learning_practice/student_centred/collaborative.c $\underline{\mathrm{fm}}$

Macaire Dominique \& Hosch Wolfram, 2004, Bilder in der Landeskunde Fernstudieneinheit 11, Berlin: Langenscheidt. Institut für JPR FH Gelsenkirchen, http://www3.w-hs.de/JPR/downloads/va 3809/semiotik.pdf oktober 2018

Macaire Dominique \& Hosch Wolfram, 2004, Bilder in der Landeskunde Fernstudieneinheit 11, Berlin:Langenscheidt, p.23

Mustafa Alltun, 2015, , vol.5 Issue: 4 Article:10 ISSN: 2146-7463, in the Journal of Educational and Instructional Studies in the World by Mustafa AlltunIshik University (November 2015, vol.5 Issue: 4 Article:10 ISSN: 2146-7463, http://clt.curtin.edu.au/teaching_learning_practice/student_centred/collaborative.c

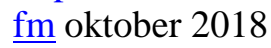

Slameto, 2012, Teorin Prestasi Belajar / persepsi eprints.uny.ac.id/8883/3/BAB\%202\%20-08404244022.pdf

Virginea Kearney, how to make visual essay https://owlcation.com > Academia > Essays How to make visual essay oktober 2018

Wagito Bimo, 2010 Pengantar Psikologi Umum. digilib.unila.ac.id/881/10/2.\%20BAB\%20II.pdf 